\title{
Trophic relationships and isotopic gradients among arctic and subarctic marine fauna*
}

\author{
Kenneth H. Dunton ${ }^{1}$, Susan M. Saupe ${ }^{2}$, Alexander N. Golikov ${ }^{3}$, Donald M. Schell², \\ Susan V. Schonberg ${ }^{1}$
}

\author{
${ }^{1}$ Marine Science Institute, The University of Texas at Austin, Port Aransas, Texas 78373-1267, USA \\ ${ }^{2}$ Institute of Marine Science, University of Alaska, Fairbanks, Alaska 99775, USA \\ ${ }^{3}$ Zoological Institute, The Soviet Academy of Sciences, Leningrad 199164, USSR
}

\begin{abstract}
Stable carbon and nitrogen isotope measurements of benthic fauna were used to identify an isotopic gradient in plankton along the subarctic and arctic coast of Alaska, and to study food web relationships in 3 geographically distinct arctic environments: the southeast Bering, the Chukchi and the eastern Beaufort Seas. Isotope measurements were also made of selected fauna from the western Beaufort Sea and from the East Siberian Sea. Results show a pronounced difference in the carbon isotope composition of suspension feeders collected in the southeastern Bering, Chukchi and western Beaufort Seas $\left(\delta^{13} \mathrm{C}=-19\right.$ to $\left.-20 \%\right)$ compared to the eastern Alaskan Beaufort and East Siberian Seas $(-25$ to $-26 \%)$. This geographic difference is greatest at lower trophic levels but is observed throughout the food web as a progressive decrease in ${ }^{13} \mathrm{C}$ content of fauna from the southeast Bering to the eastern Beaufort Sea. Predatory and omnivorous gastropods were ${ }^{13} \mathrm{C}$-enriched relative to most organisms at most geographic locations, occupying a trophic level equivalent to that of demersal fishes. Trophic relationships among fauna from the different geographical areas were similar. In the Chukchi Sea, $\delta^{13} \mathrm{C}$ and $\delta^{15} \mathrm{~N}$ values fell in a narrow range compared to other regions studied. The ${ }^{13} \mathrm{C}$ enrichment of secondary consumers in the Chukchi relative to that of zooplankton was also small. This may reflect shorter food chains, which in the Chukchi Sea is related to a more direct coupling of benthic consumers to the very high pelagic primary production, little of which is grazed before reaching the sea bed.
\end{abstract}

\section{INTRODUCTION}

Geographic gradients in the isotopic composition of marine zooplankton provide natural markers valuabie for tracing migrational patterns and feeding habits of their predators (Schell et al. 1989). A pronounced difference in zooplankton $\delta^{13} \mathrm{C}$ values between the Bering and eastern Beaufort Sea is reflected in the isotopic composition of the migratory bowhead whale (Saupe et al. in press). Analysis of these isotopic variations have contributed significantly to understanding the natural history of this animal (Schell et al. in press).

A gradient in zooplankton carbon isotope composition along the north Alaskan arctic coast by Dunton (1985) was confirmed by Saupe et al. (in press). Dunton (1985) found that $\delta^{13} \mathrm{C}$ values of calanoid copepods collected in September 1977 decreased from -23.5 to

\footnotetext{
- The University of Texas at Austin, Marine Science Institute Contribution No. 736
}

$-25.4 \%$ between the northeastern Chukchi Sea $\left(158^{\circ} \mathrm{W}\right)$ and the US-Canadian border $\left(141^{\circ} \mathrm{W}\right)$ along the Beaufort Sea coast. Saupe et al. (in press) found a similar trend in mean $\delta^{13} \mathrm{C}$ values from samples collected along the same coastline in October $1986(-22.8$ to $-26.2 \%$ ). They found that calanoid copepods were isotopically enriched in ${ }^{13} \mathrm{C}$ in the southern Chukchi and northern Bering Seas, with mean $\delta^{13} \mathrm{C}$ values of -20.7 and $-21.1 \%$ respectively.

The zooplankton $\delta^{13} \mathrm{C}$ values recorded by Dunton (1985) and Saupe et al. (in press) from the Chukchi and western Beaufort Sea agree with those reported by Rau et al. (1982) for western Beaufort Sea plankton $(-21.5$ and $-22.4 \%$ ). Rau et al. (1982) used these results to compare latitudinal trends in plankton ${ }^{13} \mathrm{C}:{ }^{12} \mathrm{C}$ ratios between northern and southern oceans and found that, although the plankton in both hemispheres showed depletions in ${ }^{13} \mathrm{C}$ with increasing latitude, the depletions were significantly less progressing toward the Arctic (about $-22 \%$ ) compared to the Antarctic ( -26 to 
$-28 \%$ ). Saupe et al. (in press) found $\delta^{13} \mathrm{C}$ values of unsorted zooplankton collected in the eastern Beaufort Sea to be ${ }^{13} \mathrm{C}$ depleted by as much as $-29.2 \%$.

The existence of a gradient in plankton ${ }^{13} \mathrm{C}:{ }^{12} \mathrm{C}$ ratios between the Bering and eastern Beaufort Sea might be questioned on the basis that (1) the isotopic measurements are of short-lived zooplankters, and (2) zooplankton biomass and species composition differ spatially and temporally across this range. The object of this research was to further define this isotopic gradient through ${ }^{13} \mathrm{C} \cdot{ }^{12} \mathrm{C}$ analyses of benthic and epibenthic consumers that are relatively long-lived, possess a variety of feeding strategies, and which are common between the southeast Bering and eastern Beaufort Sea. The collection of similar species from Chauna Bay, East Siberian Sea, $1000 \mathrm{~km}$ west of Alaska, provided a benchmark from which to compare $\delta^{13} \mathrm{C}$ values from an arctic region not likely influenced by the intrusion of Bering Sea and Alaskan coastal water (Walsh et al. in press). Measurement of both $\delta^{13} \mathrm{C}$ and $\delta^{15} \mathrm{~N}$ values of fauna from several arctic and sub-arctic areas also provided a unique opportunity to compare food webs in areas having substantially different rates of annual primary production, from less than $50 \mathrm{~g} \mathrm{C} \mathrm{m}^{-2} \mathrm{yr}^{-1}$ (Beaufort Sea; Horner 1984) to $300 \mathrm{~g} \mathrm{C} \mathrm{m}^{-2} \mathrm{yr}^{-1}$ (Bering Sea; Walsh et al. in press).

\section{MATERIALS AND METHODS}

Study area. Samples were collected from stations located at each of the 5 major geographic areas shown in Fig. 1. Nearly all fauna were collected within $20 \mathrm{~km}$ of the coastline in water depths ranging between 5 and $50 \mathrm{~m}$. The letters in Fig. 1 correspond to animals collected from: (A) the north Aleutian Shelf, southeast Bering Sea, mostly between May and July 1985 from trawls deployed along 5 transects at 10 stations: (B) the eastern Chukchi Sea, in September 1983, from trawls deployed along 3 transects between Cape Lisburne and Wainright at 15 stations; (C) the western Alaskan Beaufort Sea, in February 1983, by diving at 2 sites near Cape Halkett; (D) the eastern Alaskan Beaufort Sea, mostly in August 1986 and August 1987, by diving at 6 locations between Prudhoe Bay and the US-Canadian border; and (E) in the East Siberian Sea, in August 1987, by diving at 1 site in Chauna Bay.

Isotopic analyses. White muscle tissue samples were dissected from fish that generally ranged between 10 and $30 \mathrm{~cm}$ long. Muscle tissue was also taken from adult shrimp, gastropods, bivalves and decapods. Other invertebrates were washed of debris and analyzed whole. Polychaetes, small crustaceans and ascidians were held alive for several hours to allow gut clearance prior to analysis. All animals were dried in

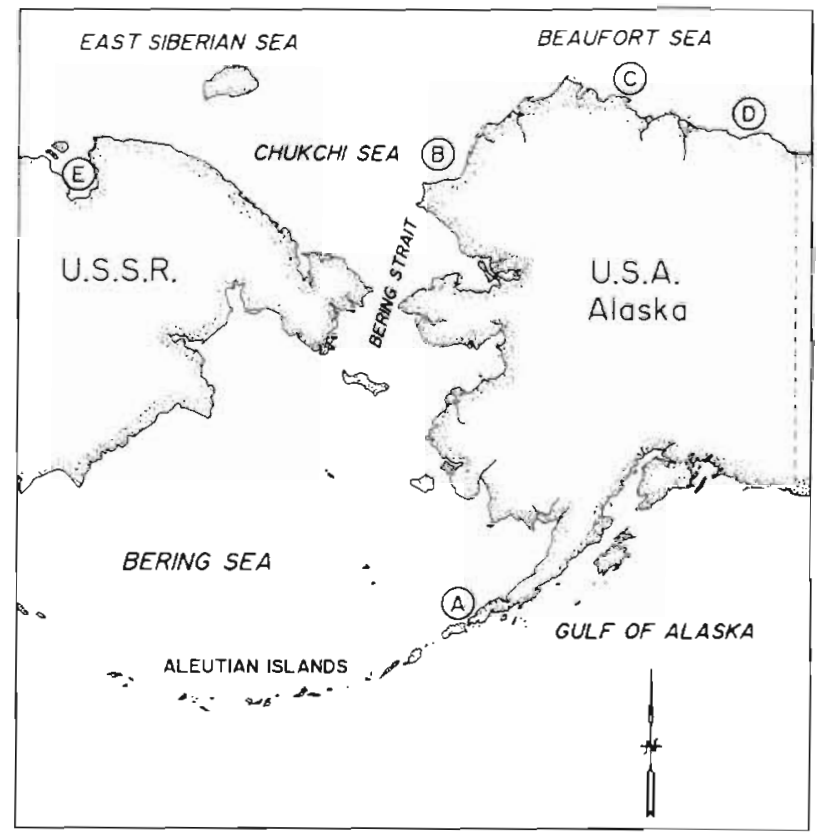

Fig. 1. Locations of collection sites. A: Southeast Bering Sea (north Aleutian Shelf); B: Chukchi Sea; C: western Alaskan Beaufort Sea; D: eastern Alaskan Beaufort Sea; E: East Siberian Sea

aluminum dishes at $50^{\circ} \mathrm{C}$. In many instances, small individuals of the same species collected at the same time were pooled to obtain sufficient material for isotopic analysis. These composites (which included several polychaete and crustacean species) consisted of at least 3 individuals.

Samples containing inorganic carbonates were soaked in $1 \mathrm{~N} \mathrm{HCl}$ for 4 to $6 \mathrm{~h}$ (or until bubbling stopped) to remove carbonates, rinsed in distilled water, and then dried at $50^{\circ} \mathrm{C}$. Subsamples of each organism or composite ( 8 to $10 \mathrm{mg}$ ) were manually ground in the presence of copper oxide and treated to yield pure $\mathrm{CO}_{2}$ and $\mathrm{N}_{2}$ for isotopic determination as described by Dunton \& Schell (1987) for carbon and Minagawa et al. (1984) for nitrogen. Results are expressed as conventional $\delta^{13} \mathrm{C}$ or $\delta^{15} \mathrm{~N}$ values, where the ratio of the sample is compared to that of a standard, where

$$
\begin{aligned}
& \delta(\%)=\left\{\left(R_{\text {sample }} / R_{\text {standard }}\right)-1\right\} \times 1000 \\
& R={ }^{13} \mathrm{C}:{ }^{12} \mathrm{C} \text { or }{ }^{15} \mathrm{~N}:{ }^{14} \mathrm{~N}
\end{aligned}
$$

and standards are PDB $\left(\delta^{13} \mathrm{C}\right)$ and nitrogen in air $\left(\delta^{15} \mathrm{~N}\right)$. Replicate isotope analyses generally differed by $<0.3 \%$

Animals were grouped by feeding type into 9 categories based on the results of earlier work with these species (Dunton \& Schell 1987) and known feeding behavior: (1) NSB, non-selective benthic suspension feeders (bivalves and ascidians), (2) SBS, selective benthic suspension feeders (sponges, hydrozoans, soft 
corals, and bryozoans); (3) BOC, benthic omnivorous crustaceans (crabs and isopods); (4) EOC, epibenthic omnivorous crustaceans (amphipods and shrimp); (5) $\mathrm{PF}$, pelagic fish (Pacific and Arctic cod); (6) PO, polychaete omnivores; (7) MO, molluscan omnivores (mostly Buccinum, Neptunea and Plicifusus); (8) MP, molluscan predators (mostly Natica); and (9) BF, demersal fish (sole, sculpins and snailfishes).

\section{RESULTS}

\section{${ }^{13} \mathrm{C}:{ }^{12} \mathrm{C}$ ratios of fauna}

${ }^{13} \mathrm{C}$ content generally increased at ascending trophic levels in the Bering. Chukchi and eastern Beaufort Seas (Fig. 2). The mean $\delta^{13} \mathrm{C}$ values of animal species

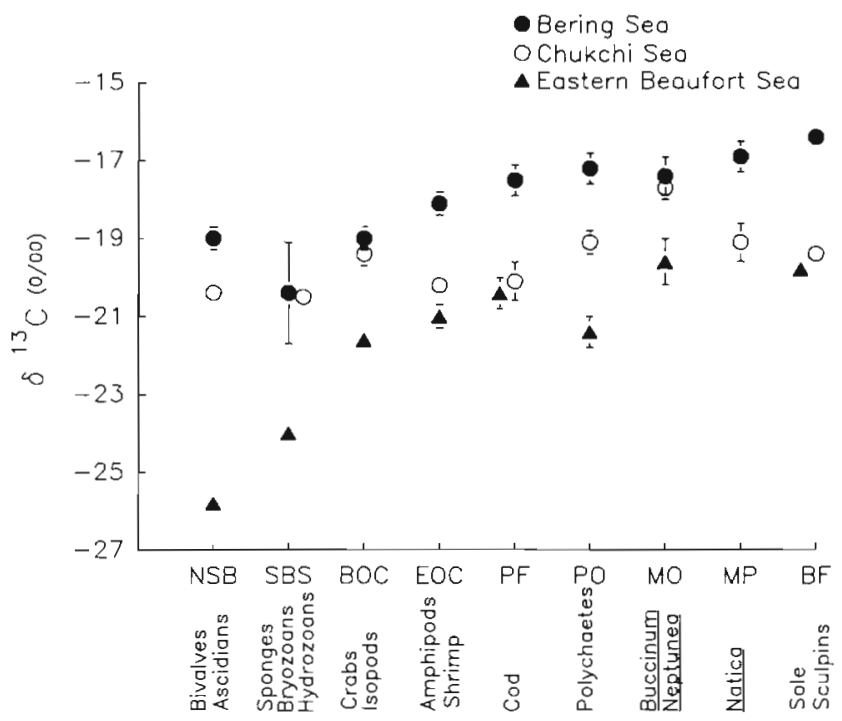

Fig. 2. $\delta^{13} \mathrm{C}$ values $(\overline{\mathrm{x}} \pm \mathrm{SE}, \mathrm{n} \geq 4$ for all points) of Alaska fauna from the southeast Bering, Chukchi and eastern Beaufort Seas. Animals are grouped according to feeding strategy. For abbreviations see 'Materials and methods'

collected at all 5 locations are shown in Table $1 .{ }^{13} \mathrm{C}$ content of the food webs generally decreased progressing from the southeast Bering to the eastern Beaufort seas, with consistent differences in mean feeding group $\delta^{13} \mathrm{C}$ values between geographic areas. Animals were ${ }^{13} \mathrm{C}$-enriched in the Bering Sea and ${ }^{13} \mathrm{C}$ depleted in the eastern Beaufort Sea, with the Chukchi Sea fauna intermediate between the 2 extremes (Fig. 2). The differences in $\delta^{13} \mathrm{C}$ between regions were greatest at the lower trophic levels. In the eastern Beaufort Sea, the mean $\delta^{13} \mathrm{C}$ values of non-selective $(-25.8 \%)$ and selective $(-24.0 \%)$ benthic suspension feeders, benthic omnivorous crustaceans $(-21.6 \%)$, polychaetes $(-21.4 \%)$ and molluscan omnivores $(-19.6 \%)$ were significantly lower $(\mathrm{p}<0.05,1$-way ANOVA) than for the same species from either the Chukchi or Bering Seas. At higher trophic levels, the difference in $\delta^{13} \mathrm{C}$ values between the eastern Beaufort and Chukchi Seas remained below $2.5 \%$, considerably less than the initial $6.4 \%$ difference found in non-selective suspension feeders. The range of all feeding group mean $\delta^{13} \mathrm{C}$ values were lowest in the Chukchi Sea $(-18.2$ to $-20.5 \%$ ), highest in the eastern Beaufort Sea $(-19.6$ to $25.8 \%$ ) , and intermediate in the southeast Bering Sea $(-16.4$ to $-20.4 \%)$.

Comparisons of the geographic trends in the carbon isotope ratios of filter feeders and secondary consumers common to the eastern and western Beaufort, Chukchi and southeast Bering Seas are shown in Fig. 3. The $\delta^{13} \mathrm{C}$ values of filter feeders in the eastern Beaufort were significantly lower $(p<0.05,1$-way ANOVA) than those from all other areas. Geographic differences among secondary consumers were not as pronounced, although a trend of increasing ${ }^{13} \mathrm{C}$ depletion is apparent from the southeast Bering to the eastern Beaufort Sea. Filter feeders and secondary consumers in the western Beaufort Sea were closer in isotopic composi-
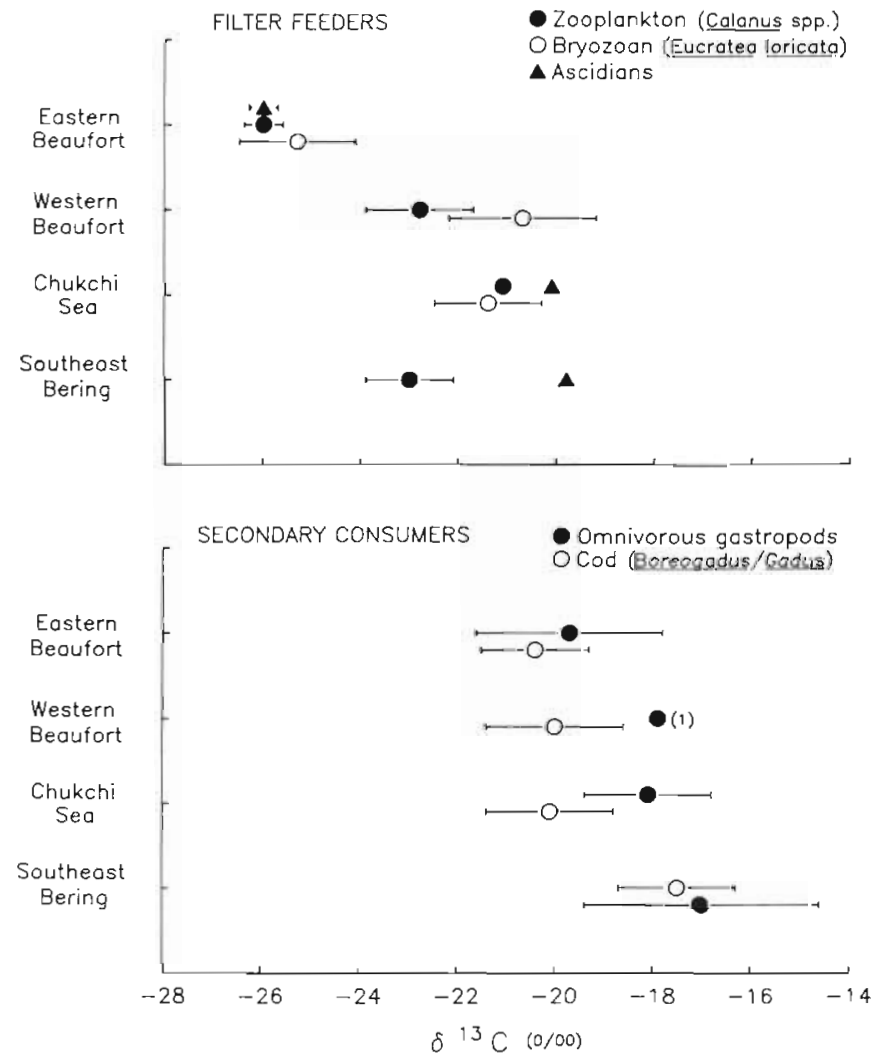

Fig. 3. $\delta^{13} \mathrm{C}$ values $(\overline{\mathrm{x}} \pm 95 \%$ confidence limits) for filter feeders and secondary consumers common to 4 geographic areas in Alaska. Omnivorous gastropods include only Buccinum and Neptunea spp. Zooplankton data from Saupe (1989) and Saupe et al. (in press) 
Table $1 . \delta^{13} \mathrm{C}$ values $(\%)$ of fauna collected at 5 locations in Alaskan and Siberian waters. Values are $\overline{\mathrm{x}} \pm \mathrm{SE}(\mathrm{n})$ for $\mathrm{n}>1$

\begin{tabular}{|c|c|c|c|c|c|}
\hline Organism & Bering Sea & Chukchi Sea & W. Beaufort Sea & E. Beaufort Sea & E. Siberian Sea \\
\hline \multicolumn{6}{|l|}{ PORIFERA } \\
\hline Halichondria panicea & & $-20.6 \pm 0.2(3)$ & & $-23.7 \pm 0.5(5)$ & \\
\hline Haliclona gracilis & & & & $-24.5 \pm 0.3(12)$ & \\
\hline Phakettia cribrosa & & -19.3 & & $-23.4 \pm 0.1\{12\}$ & \\
\hline Suberites domicula & $-23.6 \pm 1.0(2)$ & & & $-22.3 \pm 0.2(8)$ & \\
\hline \multicolumn{6}{|l|}{ CNIDARIA } \\
\hline \multicolumn{6}{|l|}{ Hydrozoa } \\
\hline Sertularia spp. & $-20.7 \pm 0.5\{2\}$ & -20.4 & & $-25.5 \pm 0.6(3)$ & \\
\hline Thuiaria sp. & & -19.7 & & -26.7 & \\
\hline \multicolumn{6}{|l|}{ Anthozoa } \\
\hline Gersemia rubiformis & & $-20.9 \pm 0.2(3)$ & & $-23.4 \pm 0.3(8)$ & \\
\hline Unidentified anemone & -19.6 & & & & \\
\hline \multicolumn{6}{|l|}{ ANNELIDA } \\
\hline \multicolumn{6}{|l|}{ Polychaeta } \\
\hline Antinoella badia & & $-20.2 \pm 0.4(2)$ & & & \\
\hline Axiothella catenata & & -17.8 & & & \\
\hline Chaetozone setosa & & & & -21.5 & \\
\hline Cistenides granulata & & & & & $-23.1 \pm 0.0(2)$ \\
\hline Eunoe depressa & & $-19.1 \pm 0.3(2)$ & & & \\
\hline Flabelligeridae & & & & -19.6 & \\
\hline Gattyana ciliata & & -18.8 & & & \\
\hline Harmothoe imbricata & & -19.4 & & & \\
\hline Lumbrineris sp. & & -19.6 & & & \\
\hline Nephtys caeca & $-16.5 \pm 0.2(5)$ & & & & \\
\hline Nicolea zostericola & & & & -22.0 & \\
\hline Scalibregma inflatum & & -17.6 & & & \\
\hline Scoloplos armiger & & & & -21.4 & \\
\hline Terebellides stroemi & & & & $-21.8 \pm 0.1(2)$ & \\
\hline \multicolumn{6}{|l|}{ MOLLUSCA } \\
\hline \multicolumn{6}{|l|}{ Gastropoda } \\
\hline Buccinum spp. & $-17.6 \pm 0.4(2)$ & $-17.7 \pm 0.3(3)$ & -17.9 & -19.9 & \\
\hline Bulbus fragilis & & $-19.8 \pm 1.0(2)$ & & & \\
\hline Margarites costalis & & $-17.0 \pm 0.1(3)$ & & & \\
\hline Natica clausa $a^{a}$ & $-17.1 \pm 0.5(4)$ & $-17.9 \pm 0.2(3)$ & & & \\
\hline Neptunea spp. & -16.0 & $-18.5 \pm 1.0(3)$ & & $-19.6 \pm 0.9(4)$ & -22.1 \\
\hline Plicifusus kroyeri & -18.3 & & & -19.5 & \\
\hline Polinices pallidus ${ }^{b}$ & -16.2 & $-19.3 \pm 1.1(2)$ & & & \\
\hline Solariella obscura & & -17.6 & & & \\
\hline Velutina undata & & -21.0 & & & \\
\hline \multicolumn{6}{|l|}{ Polyplacophora } \\
\hline Amicula vestita & & $-17.6 \pm 0.5(4)$ & & & \\
\hline \multicolumn{6}{|l|}{ Bivalvia } \\
\hline Astarte borealis ${ }^{c}$ & $-19.7 \pm 0.4(3)$ & & & & $-24.7 \pm 0.3(4)$ \\
\hline Clinocardium ciliatum $^{d}$ & -19.0 & -20.0 & & & \\
\hline Cyclocardia crebricostata & $-18.8 \pm 0.4\{4\}$ & & & & \\
\hline Hiatella arctica & & $-20.4 \pm 0.1(3)$ & & & \\
\hline Musculus corrugatus & & & & $-25.5 \pm 0.2(6)$ & \\
\hline Mytilus edulis & & $-21.1 \pm 0.2(2)$ & & & \\
\hline Serripes groenlandicus & & $-20.2 \pm 0.0(3\}$ & & & \\
\hline Yoldia hyperborea & & -20.1 & & & \\
\hline \multicolumn{6}{|l|}{ ARTHROPODA } \\
\hline \multicolumn{6}{|l|}{ Crustacea-Cirripedia } \\
\hline Balanus crenatus & -19.1 & -21.6 & $-19.8 \pm 0.0(2)$ & & \\
\hline \multicolumn{6}{|l|}{$\begin{array}{l}\text { Crustacea-Malacostraca } \\
\text { Isopoda }\end{array}$} \\
\hline $\begin{array}{l}\text { Saduria entomon } \\
\text { Tecticeps sp. }\end{array}$ & -18.4 & $\begin{array}{l}-19.6 \\
-20.0 \pm 0.4(2)\end{array}$ & $-19.2 \pm 0.3(3)$ & $-21.6 \pm 0.1\{14\}$ & -23.2 \\
\hline
\end{tabular}


Table 1 (continued)

\begin{tabular}{|c|c|c|c|c|c|}
\hline Organism & Bering Sea & Chukchi Sea & W. Beaufort Sea & E. Beaufort Sea & E. Siberian Sea \\
\hline \multicolumn{6}{|l|}{ Amphipoda } \\
\hline Acanthostephia behregensis & & $-19.5 \pm 0.2(4)$ & & $-19.7 \pm 0.5(4)$ & \\
\hline Anonyx sarsidnugax & $-20.1 \pm 1.6(2)$ & $-21.1 \pm 0.2(7)$ & & $-22.8 \pm 1.2(2)$ & \\
\hline Atylus carinatus & & -21.8 & & $-20.6 \pm 0.5(8)$ & \\
\hline Boeckosimus affinis & & & & $-22.9 \pm 0.4(2)$ & \\
\hline Gammaracanthus loricatus & & & & & $-21.1 \pm 0.3(3)$ \\
\hline Gammarus setosus & & & & -20.2 & $-23.3 \pm 0.2(2)$ \\
\hline Onisimus litoralis & & & & -22.2 & \\
\hline Weyprechtia sp. & & -19.0 & & & \\
\hline \multicolumn{6}{|l|}{ Decapoda } \\
\hline Cancer pygmaeus & -19.0 & & & & \\
\hline Chionoecetes opilio & -19.0 & $-18.6 \pm 0.2(2)$ & & & \\
\hline Crangon dalli & $-17.9 \pm 0.2(15)$ & & & & \\
\hline Hyas coarctatus alutaceus & & -18.6 & & & \\
\hline Nectocrangon spp. & & $-19.5 \pm 0.1(6)$ & & & \\
\hline Pagurus trigonocheirus & $-18.8 \pm 0.4(3)$ & -20.3 & -18.4 & & \\
\hline \multicolumn{6}{|l|}{ BRYOZOA } \\
\hline Alcyonidium gelatinosum & & $-20.6 \pm 0.0(2)$ & & $-25.8 \pm 0.3(2)$ & \\
\hline Carbasea carbasea & & & & -25.3 & \\
\hline Eucratea loricata & & $-21.4 \pm 0.3(2)$ & $-20.7 \pm 0.4(3)$ & $-25.7 \pm 0.4(8)$ & \\
\hline Flustra spp. & & $-19.1 \pm 0.0(2)$ & & $-23.9 \pm 0.5(3)$ & \\
\hline Flustrella sp. & $-17.0 \pm 1.4(2)$ & -21.1 & -20.4 & $-23.2 \pm 0.7(4)$ & \\
\hline \multicolumn{6}{|l|}{ ECHINODERMATA } \\
\hline \multicolumn{6}{|l|}{ Asteroidea } \\
\hline Leptasterias spp. & $-17.5 \pm 0.5(2)$ & -20.6 & & & \\
\hline \multicolumn{6}{|l|}{ Ophiuroidea } \\
\hline Ophelia limacina & $-18.0 \pm 0.6(5)$ & & & & \\
\hline Stegophiura nodosa & & $-18.8 \pm 0.1(2)$ & & $-21.0 \pm 0.6(2)$ & \\
\hline \multicolumn{6}{|l|}{ Holothuroidea } \\
\hline Cucumaria sp. & -17.0 & & & & \\
\hline \multicolumn{6}{|l|}{ UROCHORDATA } \\
\hline \multicolumn{6}{|l|}{ Ascidiacea } \\
\hline Boltenia ovifera & -19.8 & $-20.1 \pm 0.0(2)$ & & & \\
\hline Chelyosoma macleayanum & & -21.1 & & & \\
\hline Mogula griffithsii & & & $-26.1 \pm 0.1(6)$ & & \\
\hline Rhizomogula globularis & & & $-25.8 \pm 0.3(3)$ & $-24.5 \pm 0.2(4)$ & \\
\hline \multicolumn{6}{|l|}{ VERTEBRATA } \\
\hline \multicolumn{6}{|l|}{ Osteichthyes } \\
\hline Boreogadus saida & & $-20.1 \pm 0.5(5)$ & $-20.0 \pm 0.4(4)$ & $-20.4 \pm 0.5(8)$ & \\
\hline Gadus macrocephalus & $-17.5 \pm 0.4(5)$ & & & & \\
\hline Hippoglossoides elassodon & & -15.9 & & & \\
\hline Hippoglossus stenolepis & -17.1 & & & & \\
\hline Lepidopsetta bilineata & $-17.0 \pm 0.5(6)$ & & & & \\
\hline Leptocottus armatus & $-15.4 \pm 0.4(4)$ & & & & \\
\hline Limanda aspera & $-16.6 \pm 0.2(11)$ & & & & \\
\hline Liopsetta glacialis & & & & $-19.9 \pm 0.2(2)$ & \\
\hline Lipanis spp. & & -20.5 & & -19.5 & \\
\hline Lycodes sp. & & -19.2 & & & \\
\hline Mallatus villosus & & & & $-20.7 \pm 0.3(2)$ & \\
\hline Myoxocephalus quadricornis & -14.8 & $-19.2 \pm 0.3(7)$ & & $-19.8 \pm 0.2(4)$ & \\
\hline Paraliparis deani & -18.1 & & & & \\
\hline Platichthys stellatus & $-16.1 \pm 0.6(6)$ & & & & \\
\hline \multicolumn{6}{|l|}{ a Natica $=$ Cryptonatica } \\
\hline \multicolumn{6}{|l|}{ b Palinices = Lunatia } \\
\hline \multicolumn{6}{|l|}{${ }^{\circ}$ Astarte $=$ Iridontia } \\
\hline${ }^{\mathrm{C}}$ Clinocardium $=$ Cillatocardium & & & & & \\
\hline
\end{tabular}




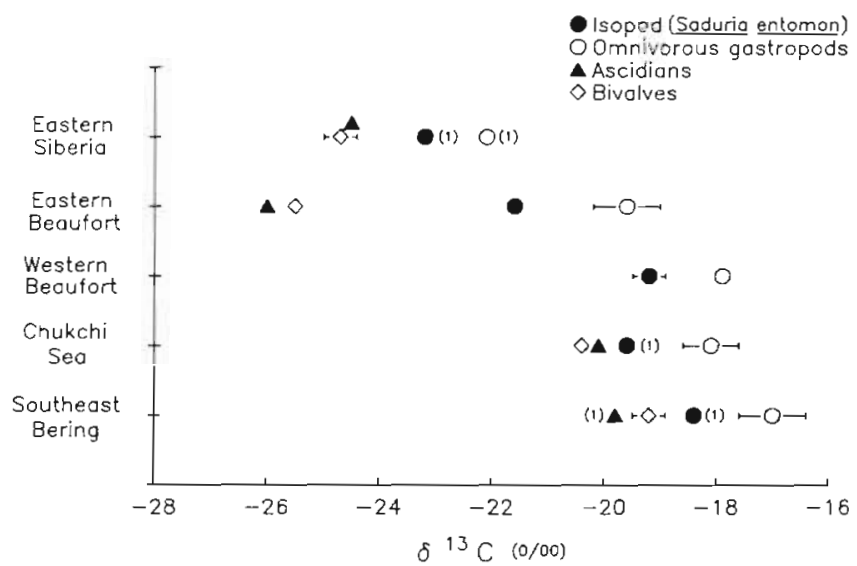

Fig. 4. $\delta{ }^{13} \mathrm{C}$ values ( $\overline{\mathrm{x}} \pm \mathrm{SE}, \mathrm{n} \geq 3$ except where noted) for species common to Siberian and Alaskan coastal waters. Omnivorous gastropods include Buccinum and Neptunea spp.

Compositions of remaining groups are listed in Table 1

tion to those from the Chukchi and southeast Bering Seas than to the same species in the geographically closer eastern Beaufort Sea. In contrast, East Siberian Sea species were noticeably depleted in ${ }^{13} \mathrm{C}$ (Table 1 ; Fig. 4 ) compared to the same organisms from the western Beaufort, Chukchi and southeast Bering Seas. The $\delta^{13} \mathrm{C}$ values of eastern Siberian species most closely resembled those from the eastern Beaufort Sea (Fig. 4).

\section{${ }^{15} \mathrm{~N}:{ }^{14} \mathrm{~N}$ ratios of fauna}

Analysis of nitrogen stable isotope ratios showed general trends of increasing $\delta^{15} \mathrm{~N}$ with trophic level but failed to show large or distinct geographic differences except for zooplankton (Table 2). The mean $\delta^{15} \mathrm{~N}$ value of calanoid copepods from the eastern Beaufort Sea $(9.4 \%$ ) was significantly lower ( $p<0.05$, t-test) than the mean value for copepods from the western Beaufort Sea $(11.4 \%)$. Chukchi and southeast Bering Sea copepods were also ${ }^{15} \mathrm{~N}$ enriched relative to Beaufort Sea copepods with $\delta^{15} \mathrm{~N}$ values that averaged $11.2 \%$ for 3 samples (Table 2). $\delta^{15} \mathrm{~N}$ data generally agreed with $\delta^{13} \mathrm{C}$ results on the relative trophic positions of organisms among the various food webs. The omnivorous gastropod Buccinum and benthic fishes were usually most enriched in ${ }^{13} \mathrm{C}$ and ${ }^{15} \mathrm{~N}$, while omnivorous demersal crustaceans displayed the least ${ }^{13} \mathrm{C}$ and ${ }^{15} \mathrm{~N}$ enrichments (Fig. 5). The range in $\delta^{15} \mathrm{~N}$ values was smallest in the Chukchi Sea (11.1 to $15.2 \%$ ), highest in the eastern Beaufort Sea ( 9.4 to $15.2 \%$ ), and intermediate in the southeast Bering Sea (11.2 to $16.2 \%$ )

\section{DISCUSSION}

\section{Geographic trends in carbon isotope ratios}

These results confirm the presence of the longitudinal gradient in zooplankton ${ }^{13} \mathrm{C}:{ }^{12} \mathrm{C}$ ratios reported by Dunton (1985) across the Alaskan Beaufort Sea, and the ${ }^{13} \mathrm{C}$ depletion of eastern Beaufort Sea zooplankton relative to zooplankton from the Chukchi or Bering Sea (Saupe et al. in press). This geographic difference is most pronounced at lower trophic levels among sessile perennial benthic suspension feeders which directly consume phytoplankton or small zooplankters. The mean $\delta^{13} \mathrm{C}$ values of other feeding groups are also lowest in the eastern Beaufort Sea compared with the Chukchi or southeastern Bering Sea, but these differences are not as large. This may reflect trophic structure and energy transfer differences or indicate that another source of ${ }^{13} \mathrm{C}$ enriched carbon is utilized by higher consumers, which is either not available or consumed by benthic suspension feeders.

Our isotopic measurements were primarily directed at benthic invertebrates, many of which are long-lived perennial species of restricted mobility. Our results

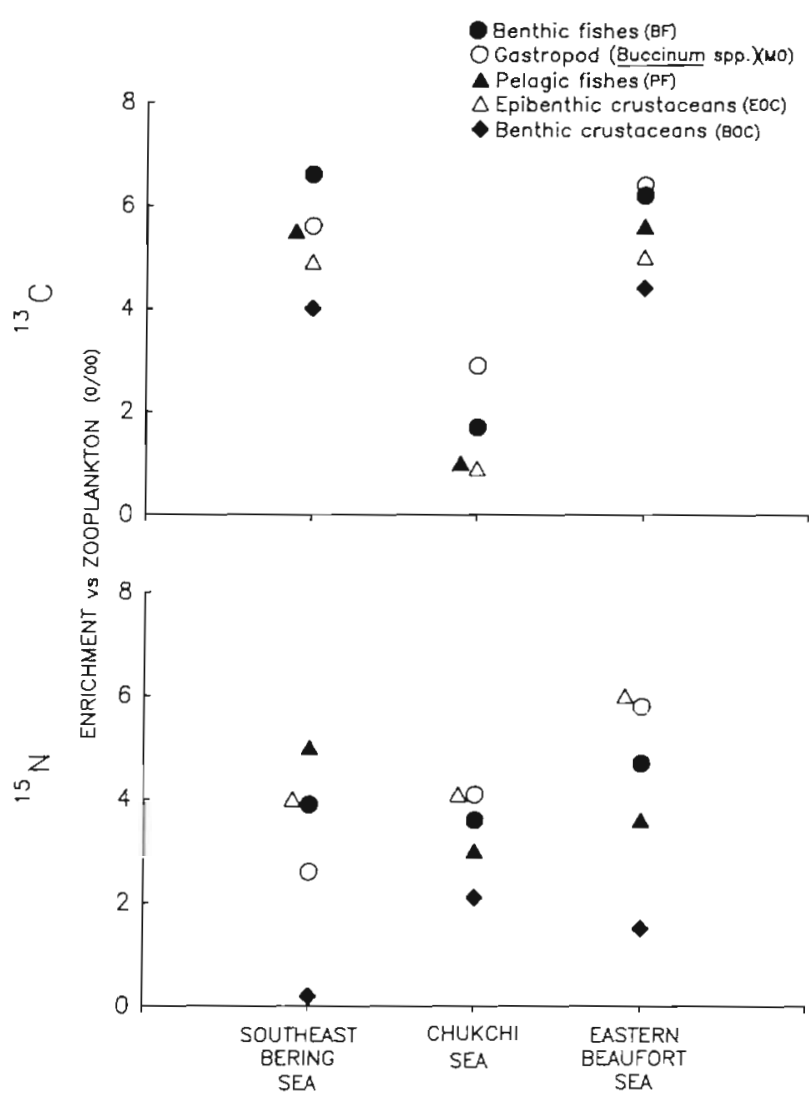

Fig. 5. Trophic ${ }^{13} \mathrm{C}$ and ${ }^{15} \mathrm{~N}$ enrichments of secondary consumers versus zooplankton (Calanus spp.) from the southeast Bering, Chukchi and eastern Alaskan Beaufort Seas 
Sea shelf, which include the intrusion of warm Bering Sea and Alaskan coastal water into the Beaufort Sea (Mountain 1974) and an upwelling in the eastern Beaufort Sea (Hufford 1974, Mountain 1974). Less is known about the East Siberian Sea where $\delta^{13} \mathrm{C}$ values are similar to those of the eastern Beaufort.

Our data show that long-lived sessile benthic fauna of the same species can possess large isotopic differences within $2^{\circ}$ latitude along a longitudinal gradient of only $300 \mathrm{~km}$ (western to eastern Beaufort Sea). Rau et al. (1982) analyzed 'arctic' zooplankton samples from the western Beaufort Sea to compare with antarctic species, and concluded that antarctic zooplankton had significantly more negative $\delta^{13} \mathrm{C}$ values. Our results show that $\delta^{13} \mathrm{C}$ values of calanoid copepods collected from the eastern Beaufort Sea range from -25 to $-27 \%$, close to the range for unsorted zooplankton in south polar seas (Sackett et al. 1965, Eadie \& Jeffrey 1973). Thus, the difference in the trends of plankton ${ }^{13} \mathrm{C}$ depletion with increasing latitude between both hemispheres may not be as significant as Rau et al. (1982) previously reported.

\section{Geographic differences in food web structure}

Carbon and nitrogen isotopic analyses revealed that trophic relationships among fauna were basically similar between the eastern Beaufort, Chukchi and Bering Seas. Isotope enrichment occurred with increasing trophic level, and there was general agreement in the might be questioned on the basis that all samples were not collected in the same year and in the same season at all geographic locations. However, comparison of available carbon isotope data of species collected between seasons within the same year (southeast Bering Sea) or in same seasons between years (eastern Beaufort Sea) seldom revealed mean values that differed more than $1 \%$. Seasonal and annual differences were usually less than $0.4 \%$. Comparison of the $\delta^{13} \mathrm{C}$ values of Bering Sea species analyzed in this study to the same species collected by McConnaughey \& McRoy (1979) a decade earlier in the same region also revealed differences that averaged less than $1 \%$ in most cases. In addition, the food web relations described by McConnaughey \& McRoy (1979) were nearly identical to those reported here; the most ${ }^{13} \mathrm{C}$ enriched benthic invertebrates include predatory gastropods, the most ${ }^{13} \mathrm{C}$-depleted, ascidians. Finally, the mean $\delta^{13} \mathrm{C}$ values reported here are characterized by similar coefficients of variation as reported in other field studies of this type (Mills et al. 1984, Fry 1988).

The cause of the distinct geographical gradient in zooplankton and benthic fauna isotopic composition, which originates in the phytoplankton, is not understood. Mechanisms that may account for ${ }^{13} \mathrm{C}$ depletion in eastern Beaufort Sea phytoplankton have been discussed in relation to differential isotopic fractionation caused by temperature gradients and/or the variation in the isotopic composition of the inorganic carbon source (Dunton 1985). Both mechanisms are based on known oceanographic features of the Alaskan Beaufort

Table 2. $\delta{ }^{15} \mathrm{~N}$ values $(\%)$ of fauna collected at 4 locations in Alaskan coast. Values are $\overline{\mathrm{x}} \pm \mathrm{SE}(\mathrm{n})$ for $\mathrm{n}>1$

\begin{tabular}{|c|c|c|c|c|}
\hline Organism & Bering Sea & Chukchi Sea & W. Beaufort Sea & E. Beaufort Sea \\
\hline \multicolumn{5}{|l|}{ MOLLUSCA } \\
\hline Buccinum spp. & $13.8 \pm 0.4(2)$ & $15.2 \pm 0.3(2)$ & 17.1 & 15.2 \\
\hline \multicolumn{5}{|l|}{ ARTHROPODA } \\
\hline Calanus spp. & $11.2 \pm 0.6(2)$ & 11.1 & $11.4 \pm 0.1(6)$ & $9.4 \pm 0.3(6)$ \\
\hline \multicolumn{5}{|l|}{$\begin{array}{l}\text { Crustacea-Malacostraca } \\
\text { Isopoda }\end{array}$} \\
\hline Saduria entomon & 10.1 & 14.4 & & $10.9 \pm 0.7(3)$ \\
\hline \multicolumn{3}{|l|}{ Amphipoda } & & 15.4 \\
\hline \multicolumn{5}{|l|}{ Decapoda } \\
\hline $\begin{array}{l}\text { Crangon dalli } \\
\text { Pagurus trigonocheirus }\end{array}$ & $\begin{array}{l}14.4 \pm 0.4(2) \\
12.0 \pm 0.2(2)\end{array}$ & 11.9 & 12.0 & \\
\hline \multicolumn{5}{|l|}{ VERTEBRATA } \\
\hline Boreogadus saida & & $14.1 \pm 0.5(3)$ & $12.6 \pm 0.3(4)$ & $13.0 \pm 0.3(6)$ \\
\hline Gadus macrocephalus & $16.2 \pm 1.3(3)$ & & & \\
\hline Liparis spp. & & 14.1 & & \\
\hline Myoxocephalus quadricornis & & $15.0 \pm 0.2(2)$ & & $14.1 \pm 0.0(2)$ \\
\hline
\end{tabular}


hierarchical order of the feeding groups as defined by both $\delta^{13} \mathrm{C}$ and $\delta^{15} \mathrm{~N}$ data (Figs. 2 and 5). Because of the diversity and complexity of these systems, assigning trophic levels to various species is impractical, but it is apparent that omnivorous and predaceous gastropod invertebrates can occupy trophic levels equivalent to those possessed by demersal fishes. An analysis of food web structure in the southeast Bering Sea by McConnaughey \& McRoy (1979) revealed a similar relationship in which predatory gastropods were the most ${ }^{13} \mathrm{C}$-enriched invertebrate animals collected (including mammals and birds). Few offshore isotopic studies have included gastropods in food web analyses, and as a result, their role as one of the top benthic predators is often overlooked (Mills et al. 1984, Minagawa \& Wada 1984)

Although the trophic relations among fauna from the different geographic areas were similar, the range of $\delta^{13} \mathrm{C}$ values recorded in each system varied considerably. For example, the range in mean carbon isotope ratios among the 9 feeding groups (Fig. 2) was greatest in the eastern Beaufort $(6 \%)$, least in the Chukchi $(2 \%)$, and intermediate in the southeast Bering Sea $(4 \%)$. In addition, secondary consumers in the Chukchi Sea showed the least enrichment of ${ }^{13} \mathrm{C}$ relative to zooplankton, compared to Bering and Beaufort Sea fauna, which were nearly equal (Fig. 5).

These data suggest that Chukchi Sea benthic fauna are more closely coupled to primary production. There is some biological evidence to support this hypothesis. First, the northwestern Bering and Chukchi Seas are characterized by an extremely rich benthos (Grebmeier et al. 1988). This benthos is supported by primary production rates that average 250 to $300 \mathrm{~g} \mathrm{C} \mathrm{m}^{-2} \mathrm{yr}^{-1}$ annually (Walsh et al. in press), compared to about half that for the southeast Bering Sea (Walsh \& McRoy 1986, Walsh et al. in press), and 10 to $25 \mathrm{~g} \mathrm{C} \mathrm{m}^{-2} \mathrm{yr}^{-1}$ for the Beaufort Sea (Alexander 1974, Horner 1984). Secondly, Coyle \& Cooney (1988) found that the vast majority of spring carbon production in this area is ungrazed by zooplankton, presumably sinking directly to the seafloor. Grebmeier (1987) reported that nearly $70 \%$ of the primary production produced in northern Bering and Chukchi Sea waters escapes pelagic consumption and falls to the seafloor, compared to $12 \%$ for Alaskan coastal water which predominates in the southeast Bering Sea; the quality of the falling organic matter is also higher, as reflected in lower $\mathrm{C} / \mathrm{N}$ ratios in Bering and Chukchi Sea sediments not overlain by Alaskan coastal water (Grebmeier et al. 1988).

The relative variations in $\delta^{15} \mathrm{~N}$ among fauna from the 3 geographic regions in this study were similar in direction as that noted for carbon. Although not as pronounced, the range in $\delta^{15} \mathrm{~N}$ values of secondary consumers varied from a high of about $6 \%$ in the eastern Beaufort Sea to a low of $4 \%$ in the Chukchi with an intermediate value of $5 \%$ in the southeastern Bering Sea. No large differences were observed between the ${ }^{15} \mathrm{~N}$ enrichment of consumers relative to zooplankton as in ${ }^{13} \mathrm{C}$ (Fig. 5), but this may reflect differing nitrogen fractionations during microbial transformations of available food. Generally, bacterial cells become enriched in ${ }^{13} \mathrm{C}$ relative to their substrate, but nitrogen assimilation by microflora can result in either ${ }^{15} \mathrm{~N}$ depletion, ${ }^{15} \mathrm{~N}$ enrichment, or no change, depending on the chemical nature of the substrate (Macko \& Estep 1984). Thus, nitrogen isotopes may not be reliable food web tracers (or track ${ }^{13} \mathrm{C}$ enrichments) at lower trophic levels in detritus-based food webs.

Our results show the dual utility of stable carbon and nitrogen isotope ratios in food web studies. A knowledge of the feeding strategies of benthic and epibenthic fauna provides insight into understanding and interpreting isotopic variations in food webs, and the dynamic nature of trophic relationships among organisms. In this study, geographic gradients of the isotope ratios in benthic fauna indicate relative differences of benthic-pelagic coupling between food webs in different regions. These measurements also provide circumstantial evidence for transport of organic material from the northern Bering Sea to the Chukchi and western Beaufort Seas.

Acknowledgements. We are particularly grateful to P. Parker T. Whitledge, R. Scalan and B. Sirenko for technical assistance and helpful discussions. We also thank $\mathrm{S}$. Horner and $\mathrm{H}$ Garrett for help with data synthesis and manuscript preparation. J. Lawrence and 2 anonymous reviewers provided excellent comments on earlier drafts that improved the manuscript considerably. Field support was provided by the ship and crew of the 'Miller Freeman' and 'Discoverer', Exxon Company, USA, Standard Alaska Production Company, and by the Bureau of Land Management through an interagency agreement with the National Oceanic and Atmospheric Administration.

\section{LITERATURE CITED}

Alexander, V (1974). Primary productivity regimes of the nearshore Beaufort Sea, with reference to potential roles of ice biota. In: Reed, J. C., Sater, J. E (eds.) The coast and shelf of the Beaufort Sea. Arct. Inst. N. Amer., Arlington, p. 609-632

Coyle, K. O., Cooney, R. T. (1988). Estimating carbon flux to pelagic grazers in the ice-edge zone of the eastern Bering Sea. Mar. Biol. 98: 299-306

Dunton, K. (1985). Zooplankton ${ }^{13} \mathrm{C}:{ }^{12} \mathrm{C}$ ratios in the Western Arctic Ocean: a longitudinal gradient. Ph.D. dissertation, Univ. Alaska, Fairbanks

Dunton, K., Schell, D. M. (1987). Dependence of consumers on macroalgal (Laminaria solidungula) carbon in an Arctic kelp community: $\delta^{13} \mathrm{C}$ evidence. Mar. Biol. 93: 615-625

Eadie, B. J., Jeffrey, B. J. (1973). $\delta^{13} \mathrm{C}$ analyses of oceanic particulate organic matter. Mar. Chem. 1: 199-209 
Fry, B. (1988). Food web structure on Georges Bank from stable $\mathrm{C}, \mathrm{N}$, and $\mathrm{S}$ isotopic compositions. Limnol. Oceanogr. 33: 1027-1030

Grebmeier, J. M. (1987). The ecology of benthic carbon cycling in the northern Bering and Chukchi Seas. Ph.D. dissertation, Univ. Alaska, Fairbanks

Grebmeier, J. M., McRoy, C. P., Feder, H. M. (1988). Pelagicbenthic coupling on the shelf of the northern Bering and Chukchi Seas. I. Food supply source and benthic biomass. Mar. Ecol. Prog. Ser. 48: 57-67

Horner, R. (1984). Phytoplankton abundance, chlorophyll a, and primary productivity in the western Beaufort Sea. In: Barnes, P. W., Schell, D., Reimnitz, E. (eds.) The Alaskan Beaufort Sea: ecosystems and environments. Academic Press, Orlando, p. 295-310

Hufford, G. L. (1974). On apparent upwelling in the southern Beaufort Sea. J. geophys. Res. 79: 1305-1306

Macko, S. A., Estep, M. L. F. (1984). Microbial alteration of stable nitrogen and carbon isotopic compositions of organic matter. Org. Geochem. 6: 787-790

McConnaughey, T., McRoy, C. P. (1979). Food-web structure and the fractionation of carbon isotopes in the Bering Sea. Mar. Biol. 53: 257-262

Mills, E. L., Pittman, K., Tan, F. C. (1984). Food-web structure on the Scotian Shelf, eastern Canada: a study using ${ }^{13} \mathrm{C}$ as a food-chain tracer. Rapp. P.-v. Réun. Cons. int. Explor Mer 183: 111-118

Minagawa, M., Wada, E. (1984). Stepwise enrichment of ${ }^{15} \mathrm{~N}$ along food chains: further evidence and the relation between $\delta^{15} \mathrm{~N}$ and animal age. Geochim. Cosmochim. Acta 48: $1135-1140$

Minagawa, M., Winter, D. A., Kaplan, I. R. (1984). Comparison of Kjeldahl and combustion methods for measurement of

This article was presented by Professor J. M. Lawrence, Tampa, Florida, USA nitrogen isotope ratios in organic matter. Analyt. Chem. 56: $1859-1861$

Mountain, D. G. (1974). Preliminary analysis of Beaufort shelf circulation in summer. In: Reed, J. C., Sater, J. E. (eds.) The coast and shelf of the Beaufort Sea. Arct. Inst. N. Amer., Arlington, p. 27-48

Rau, G. H., Sweeney, R. E., Kaplan, I. R. (1982). Plankton ${ }^{13} \mathrm{C} \cdot{ }^{12} \mathrm{C}$ ratio changes with latitude: differences between northern and southern oceans. Deep Sea Res. 29: 1035-1039

Sackett, W. M., Eckelmann, W. R., Bender, M. L., Be, A. W. H. (1965). Temperature dependence of carbon isotope composition in marine plankton and sediments. Science 148: 235-237

Saupe, S. M. (1989). Nutrient dynamics and carbon supply to the north Aleutian Shelf nearshore ecosystem. M.S. thesis, Univ. Alaska, Fairbanks

Saupe, S. M. Schell, D. M., Griffiths, W. (in press). $\delta^{13} \mathrm{C}$ gradients in western arctic zooplankton. Mar. Biol

Schell, D. M., Saupe, S. M., Haubenstock, N. (1989). Natural isotopic abundances in bowhead whale (Balaena mysticetus) baleen: markers of aging and habitat usage. In: Rundel, P. W. et al. (eds.) Stable isotopes in ecological research. Springer-Verlag, New York, p. 260-269

Schell, D. M., Saupe, S. M., Haubenstock, N. (in press). Bowhead whale (Balaena mysticetus) growth and feeding as estimated by $\delta^{13} \mathrm{C}$ techniques. Mar. Biol

Walsh, J. J., McRoy, C. P. (1986). Ecosystem analysis in the southeastern Bering Sea. Cont. Shelf Res. 5: 259-288

Walsh, J. J., and 20 co-authors (in press). Carbon and nitrogen cycling within the Bering/Chukchi Seas: source regions for organic matter affecting AOU demands of the Arctic Ocean. Prog. Oceanogr.

Manuscript first received: October 26, 1988

Revised version accepted: May 12, 1989 